\author{
Asian Journal of \\ Medical and Biological Research \\ ISSN 2411-4472 (Print) 2412-5571 (Online) \\ www.ebupress.com/journal/ajmbr
}

\title{
Article \\ Potentiality of producing summer cauliflower as influenced by organic manures and spacing
}

\author{
Laila Farzana, Abul Hasnat M Solaiman ${ }^{*}$ and Md. Ruhul Amin \\ Department of Horticulture, Sher-e-Bangla Agricultural University, Dhaka, Bangladesh
}

*Corresponding author: Dr. Abul Hasnat M Solaiman, Department of Horticulture, Sher-e-Bangla Agricultural University, Dhaka, Bangladesh. E-mail: solaimanhort@sau.edu.bd, solaimansau@gmail.com

Received: 07 June 2016/Accepted: 23 June 2016/ Published: 30 June 2016

\begin{abstract}
The experiment was conducted to find out the effect of organic manures and spacing on the growth and yield of cauliflower in summer season. In this study, the treatment consisted of three organic manures viz. $F_{0}$ : no organic manure, $F_{1}$ : cowdung, $F_{2}$ : vermicompost and three spacing viz. $S_{1}(60 \times 30) \mathrm{cm}, S_{2}(60 \times 40) \mathrm{cm}$, $\mathrm{S}_{3}(60 \times 50) \mathrm{cm}$. Two factorial experiments were laid out in the RCBD with three replications. Significant variations in all parameter were observed due to organic manure and spacing at different days after transplanting. For organic manure, highest yield of cauliflower $\left(12.98 \mathrm{t} \mathrm{ha}^{-1}\right)$ was obtained from $\mathrm{F}_{2}$ and lowest $\left(8.24 \mathrm{tha}^{-1}\right)$ from $\mathrm{F}_{0}$. For spacing, highest yield of cauliflower $\left(11.25 \mathrm{t} \mathrm{ha}^{-1}\right)$ was obtained from $\mathrm{S} 1$ and lowest $\left(10.57 \mathrm{t} \mathrm{ha}^{-1}\right)$ from $\mathrm{S}_{3}$. For combined effect, highest yield of cauliflower $\left(13.33 \mathrm{t} \mathrm{ha}^{-1}\right)$ was obtained from $\mathrm{F}_{2} \mathrm{~S}_{1}$ and the lowest (7.91 tha ${ }^{-1}$ ) from $F_{0} S_{3}$. The highest BCR (3.79) was found from $F_{2} S_{1}$ and lowest (2.7) from $F_{0} S_{3}$. It is found from the experiment that growth and yield of summer cauliflower were positively correlated with organic manure and spacing. However, white beauty cultivars can be cultivated in summer season and use of vermicompost with $60 \times 50 \mathrm{~cm}$ spacing would be beneficial for the farmers.
\end{abstract}

Keywords: organic manures; spacing; summer cauliflower; vermicompost

\section{Introduction}

Cauliflower (Brassica oleracea var botrytis sub var. cauliflora; family Brassicaceae) is introduced in India and a very tasty and much popular vegetable in Bangladesh as well as all over the world (Swarup and Chatterjee, 1972; Rashid, 1999). In 2009-2010 cauliflower cover an area 16600 hectares with a total production of 160000 metric tones (BBS, 2011). The success or failure of cauliflower production is largely depends upon climate, especially temperature and this relationship is very intensive and complex the life cycle of cauliflower is divided into three stages based on the effect of temperature; they are vegetative growth stage, curd initiation stage and reproductive stage. Cauliflower requires a period of cold not only for curd production but also for flowering. Fujime (1983) reported that cold requirement for flower production is stronger than for curd production. Cauliflowers that are produced in autumn and winter season in the temperate region can not be grown in Bangladesh, because they do not initiate curd in the mild winter of Bangladesh. Only summer varieties of those regions initiate curd easily. Cauliflower requires a period of cold to stimulate curd initiation (Wiebe, 1972).

Many research works have shown that many organic wastes produced in the tropics have the ability to provide nutrients and enhance soil quality. The benefits of organic production on food quality and safety have created high global demand for organic products. Utilization of organic wastes from agriculture as organic fertilizer for growing crops commercially is very much dependent on the availability of organic wastes and comparability with chemical fertilizers in plant growth and yield performance. Often organic fertilizers are associated with lower yield compared to chemical fertilizers. Soil management practices have recently changed dramatically including an increased use in synthetic fertilizers and pesticides to help crop yields. However, some studies have suggested that the excessive use of these agrochemicals may actually increase pest problems in the long run 
(Altieri and Nicholls, 2003). Overall, these results propose a hypothesis that higher synthetic fertilizer inputs may lead to higher levels of herbivore damage to crops (Letourneau, 1996). Utilization of organic matter has been well documented to improve physical, chemical and biological properties of soil (Whalen et al., 2000; Tejada and Gonzalez, 2003), Cook et al. (1994) and the addition of compost to soil generally improves tilth, soil structure, infiltration, drainage and water holding capacity.

In Bangladesh, cauliflower is mainly cultivated in winter season. Summer season cauliflower cultivation is constrained due to adverse weather condition along with absence of summer tolerant varieties and proper cultural practices. Introducing hot and summer tolerant cauliflower variety might help solving of cauliflower production in the country. The production of cauliflower in summer season is a challenge whether it will grow only in winter. The demand of cauliflower is increasing day by day in summer season because of its demand to consumer for taste and nutrient value.

Spacing is another factor that was reported to be having an influence on Brassica production Widders and Price (1989) defined spacing as the distance between the plants in the row and between the rows of planted crops. Ghanti et al., (1982) and Fujiwara (2000) observed maximum results of yield contributing characters at higher spacing and a decrease as spacing between plants decreased.

Considering the above factors, the present experiment was undertaken to study the following objectives-

a) To identify the appropiate organic manure for cauliflower population.

b) To study the effect of different spacing on growth and yield of cauliflower.

c) To study the combined effect of organic manure and spacing on growth and yield of cauliflower.

\section{Materials and Methods}

\subsection{Experimental site and climate}

The field experiment was carried out at the Horticulture Farm, Sher-e-Bangla Agricultural University (SAU), Dhaka during the period from April to August, 2013. The experimental field was located at $90^{\circ} 22^{\prime} \mathrm{E}$ longitudes and $23^{\circ} 41^{\prime} \mathrm{N}$ latitude at an altitude of 8.6 meters above the sea level (UNDP, 1988). The land was in AgroEcological Zone of Madhupur tract (AEZ No-28). It was deep red brown terrace soil and belonged to "Nodda" cultivated series. The soil was sandy loam in texture having $\mathrm{pH}$ 6.06. The experimental area was under the subtropical monsoon climate, which is characterized by heavy rainfall during kharif season (April to September) and scant or no rainfall during the rest of the year. Plenty of sunshine and moderately low temperature prevails during Rabi season (October to March), which are suitable for growing cauliflower in Bangladesh. Physical and chemical properties of the initial soil are mentioned in Table 1 and monthly air temperature, rainfall and relative humidity of the experimental site stated in Table 2.

Table 1. Physical and chemical properties of the initial soil of the experiment field.

\begin{tabular}{ll}
\hline Characteristics & Value \\
\hline Practical size analysis & 16 \\
Sand $(\%)$ & 56 \\
Silt $(\%)$ & 28 \\
Clay $(\%)$ & 84 \\
Silt + Clay $(\%)$ & Silty clay loam \\
Textural class & 5.56 \\
pH & 0.25 \\
Organic matter $(\%)$ & 0.02 \\
Total N $\%)$ & 53.64 \\
Available P $(\mu \mathrm{gm} / \mathrm{gm}$ soil $)$ & 0.13 \\
Available K $(\mathrm{me} / 100 \mathrm{~g}$ soil $)$ & 9.40 \\
Available $\mathrm{S}(\mu \mathrm{gm} / \mathrm{gm}$ soil $)$ & 0.13 \\
Available B $(\mu \mathrm{gm} / \mathrm{gm}$ soil $)$ & 0.94 \\
Available $\mathrm{Zn}(\mu \mathrm{gm} / \mathrm{gm}$ soil $)$ & 1.93 \\
Available $\mathrm{Cu}(\mu \mathrm{gm} / \mathrm{gm}$ soil $)$ & 240.9 \\
Available Fe $(\mu \mathrm{gm} / \mathrm{gm}$ soil $)$ & 50.6 \\
Available $\mathrm{Mn}(\mu \mathrm{gm} / \mathrm{gm}$ soil $)$ & \\
\hline
\end{tabular}


Table 2. Monthly air temperature, rainfall and relative humidity of the experimental site during the study period (April to August, 2013).

\begin{tabular}{llcllll}
\hline Month & \multicolumn{3}{c}{ Air temperature $\left({ }^{\mathbf{0}} \mathbf{C}\right)$} & $\begin{array}{l}\text { Rainfall** } \\
(\mathbf{m m})\end{array}$ & $\begin{array}{l}\text { * Relative } \\
(\boldsymbol{\%})\end{array}$ & humidity \\
\cline { 2 - 6 } & Max. & Min. & Mean & 65 & 88.24 & \\
\hline April & 32.98 & 23.72 & 28.35 & 65.55 & \\
May & 34.00 & 24.65 & 34.33 & 155 & 79.55 & \\
June & 33.85 & 26.15 & 30.0 & 184 & 89.05 & \\
July & 34.20 & 24.50 & 29.35 & 281 & 81.20 & \\
August & 32.36 & 23.56 & 27.96 & 215 & \\
\hline
\end{tabular}

* Monthly average, ** Monthly total

\subsection{Materials and rising of Seed bed}

The varieties of cauliflower selected for the experiment were 'White beauty'. The seeds of this variety were collected from Siddique Bazar, Dhaka. Seed bed was made on 20 April for raising cauliflower seedlings. The size of the seed bed was $3 \mathrm{~m} \times 1 \mathrm{~m}$. For making seed bed the soil was well ploughed and converted into loose friable and dried masses to obtain good tilth. Weed stubbles and dead roots were removed from the seed bed. The surface of the bed was made smooth and well leveled. Well decomposed FYM@ 2-3 kg.m ${ }^{-2}$ was added at the time of bed preparation. Raised beds are necessary to avoid problem of water logging in heavy soils. Seeds were treated by Vitavax 200 WP@ $2.5 \mathrm{~g} / \mathrm{kg}$ of seed to protect some seed borne diseases such as damping off and leaf spot.

\subsection{Seed Sowing and seedling raising}

Seeds were sown on seed bed on 20 April. The soil of the seed bed was well prepared and made into loose friable mass by spading. The bed was covered with dry straw to maintain required temperature and moisture. Sowing was done thinly spaced at $5 \mathrm{~cm}$ distance and the seeds were sown at a depth of $2 \mathrm{~cm}$ and covered with a fine layer of soil followed by light watering with a water can. The cover of dry straw was removed immediately after emergence of seedlings. Light watering and weeding were done as and when needed. No chemical fertilizer was applied for raising of seedlings. Seedlings were not attacked by any kind of insect or disease. Healthy seedlings were transplanted.

\subsection{Experimental design and factors}

The experiment was conducted in Randomized Complete Block Design (RCBD) with three replications. Two factors were used in this experiment is three levels of fertilizer and three types of spacing. In the experiment, Factor A: Three levels of fertilizer: denoted as $(\mathrm{F})$, where, $\mathrm{F}_{0}$ : Control (no fertilizer); $\mathrm{F}_{1}$ : Cowdung 30 t.ha $^{-1} ; \mathrm{F}_{2}$ : Vermicompost 20 t. ha ${ }^{-1}$ and as Factor B: Three different spacing: denoted as (S) where $S_{1}: 60 \mathrm{~cm} \times 30 \mathrm{~cm} ; \mathrm{S}_{2}$ : $60 \mathrm{~cm} \times 40 \mathrm{~cm}$ and $S_{3}: 60 \mathrm{~cm} \times 50 \mathrm{~cm}$. The experiment area was first divided into 3 blocks. Each block was divided into 9 plots for the treatment combination. Therefore, the total numbers of plots were 27 and 9 treatment combinations were assigned to each block as per design of the experiment. The size of the unit plot was $1.8 \mathrm{~m} \times$ $2 \mathrm{~m}\left(3.6 \mathrm{~m}^{2}\right)$. A distance of $50 \mathrm{~cm}$ was maintained between the plot and $1 \mathrm{~m}$ between the block.

\subsection{Land preparation and fertilization}

The experimental plot was first opened on 18 May, 2013 with a power tiller and then it was exposed to the sun for five days. It was thoroughly ploughed several times with a power tiller to bring about a good tilth, suitable for growing cauliflower. Weeds and stubbles were removes as far as possible from the field and big clods were broken through laddering into tiny pieces. The amount of different types of organic manures like- Cowdung$11.00 \mathrm{~kg} \mathrm{plot}^{-1} @ 30.00$ tha $^{-1}$ and vermicompost- $7.50 \mathrm{~kg} \mathrm{plot}^{-1}$ was @ $20.00 \mathrm{t} \mathrm{ha}^{-1}$ were applied in this study. The total amount of cowdung, vermicompost and cowdung was applied during land preparation.

\subsection{Transplanting of seedlings}

The seed bed was watered before uprooting the seedling to minimize the root damage. Care was taken so that root damage was minimized and some soil should remain with the roots. Before transplanting, the roots of the seedlings were dipped in solution of Bavistin $\left(2 \mathrm{~g} . \mathrm{l}^{-1}\right.$ of water). The seedling having 5-6 true leaves were transplanted on 25 May at the spacing $60 \mathrm{~cm} \times 50 \mathrm{~cm}, 60 \mathrm{~cm} \times 40 \mathrm{~cm}$ and $60 \mathrm{~cm} \times 30 \mathrm{~cm}$ in plots. Transplanting was done in the afternoon to the experimental plot and a light irrigation was given after 
transplanting. Banana leaf sheath pieces were used to protect the seedlings from scorching sunshine. Until the seedlings were established, shading and watering were continued.

\subsection{Intercultural operations}

Transplanted seedlings were kept under careful observation to minimize damage. Replacement of injured and dead seedlings was done with healthy seedlings through the border plants. Weeding was done at 15,30 and 45 days after transplanting to keep the plots free from weeds during the entire growing period. At the time of earthing up the plants were supported with soil to avoid toppling down of the plant during the head formation. Irrigation was given as and when required after transplanting of seedling for proper growth and development. Care was taken to avoid water stress from the time of head formation to the head maturity period. During experimental period, there was heavy rainfall for several times. So it was essential to remove the excess water from the field.

\subsection{Plant protection}

Few plants were damaged by mole crickets and caterpillars which fed on the leaf epidermis and later made holes just after transplanting. In the leaves spraying with Malathion 57 EC @ 2ml per litre was done to control them. Some time, adult Cauliflower borer female laid eggs on the growing point or on the older leaves. Some plants were infected by Alternaria leaf spot disease caused by Alternaria brassicae. To prevent the spread of Alternaria leaf spot disease, Rovral 50 WP @ $20 \mathrm{~g} .10$ liter $^{-1}$ of water was sprayed.

\subsection{Harvesting and data collection}

Randomly selected ten plants were harvested from each plot for recording data to achieve the goal of experiment. Data was recorded from 10 randomly selected plants from the middle rows of each unit plot during the course of experiment. The different growth and yield parameters were recorded at 30, 50, and 70 days after transplanting (DAT) using meter scale.

\subsection{Statistical analysis}

Calculated data on various parameters under study were statistically analyzed by using MSTAT-C. Means for all the treatments were calculated and analyses of variances for all the characters were performed by ' $\mathrm{F}$ ' test. Significance of differences between pairs of treatment means was evaluated by DMRT (Gomez and Gomez, 1984).

\subsection{Economic analysis}

The cost of production was analyzed in order to find out the most economic treatment of organic manure and plant spacing. All input cost included the cost for lease of land and interests of running capital in computing the cost of production. The interests were calculated @ 15\% in simple rate. The benefit cost ratio (BCR) was calculated as follows: $\mathrm{BCR}=$ Gross return per hectare $(\mathrm{TK}) /$ Total cost of production $(\mathrm{TK})$

\section{Results and Discussion}

\subsection{Plant height}

The plant height varied significantly due to different organic manure (Figure $1 \mathrm{~A}$ ). During the period of plant growth the maximum plant height $(50.8 \mathrm{~cm})$ was observed in $F_{2}$ while, the shortest plant height $(29.2 \mathrm{~cm})$ was in $\mathrm{F}_{0}$ at $70 \mathrm{DAT}$. Organic manure ensures available essential nutrients for the plant for that organic manure gave the highest plant height compare to control. Among the different organic manure vermicompost was found more effective than other organic manure. In respect of spacing, the tallest plant $(30.9 \mathrm{~cm})$ was found in $S_{1}$ and the shortest $\left(29.2 \mathrm{~cm}\right.$ ) was in $\mathrm{S}_{3}$ at 70 DAT (Figure 1B). Results under the present experiment showed that closer spacing showed higher plant height where wider plant spacing showed lower plant height because of closer spacing plant compete for light which helps to elongate plant than the wider spacing. Moniruzzaman (2006) reported similar findings from the closest spacing. In the case of combined effect, the tallest plant $(33.1 \mathrm{~cm})$ was found from $F_{2} S_{1}$ and the shortest $\left(28.2 \mathrm{~cm}\right.$ ) was from $\mathrm{F}_{0} \mathrm{~S}_{3}$ at 70 DAT (Table 3). 


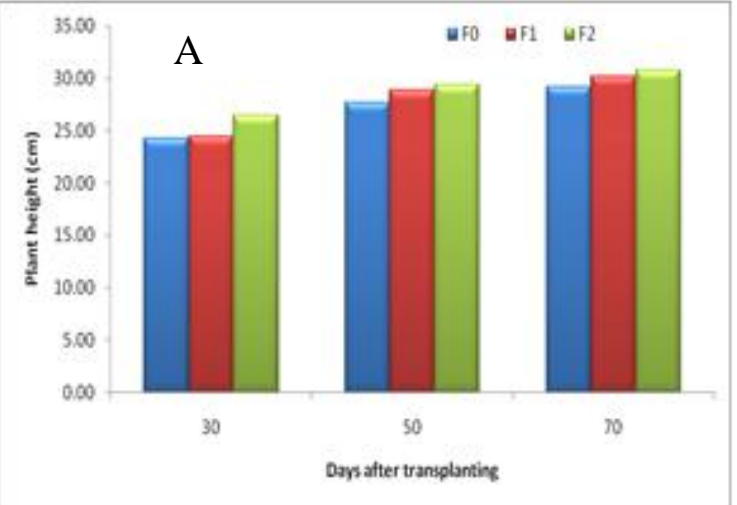

$\mathrm{F}_{0}$ - control, $\mathrm{F}_{1}$-Cowdung, $\mathrm{F}_{2}$ - Vermicompost

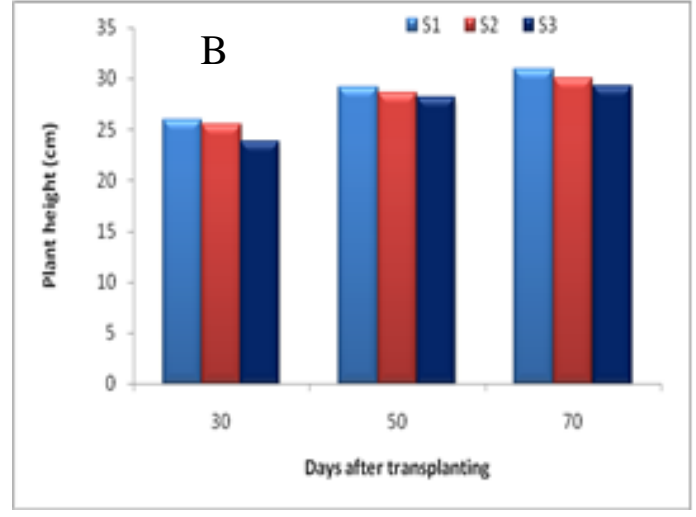

$\mathrm{S}_{1^{-}} 60 \times 30 \mathrm{~cm}, \mathrm{~S}_{2^{-}} 60 \times 40 \mathrm{~cm}, \mathrm{~S}_{3^{-}} 60 \times 50 \mathrm{~cm}$

Figure 1. Effect of organic manure (A) and spacing (B) on plant height of cauliflower at different days after transplanting.

Table 3. Combined effect of organic manure and spacing on plant height and number of leaf per plant of cauliflower.

\begin{tabular}{|c|c|c|c|c|c|c|c|c|c|c|c|c|}
\hline \multirow{2}{*}{ Treatment } & \multicolumn{6}{|c|}{ Plant height (cm) } & \multicolumn{6}{|c|}{ Number of leaf per plant } \\
\hline & \multicolumn{2}{|l|}{30 DAT } & \multicolumn{2}{|c|}{50 DAT } & \multicolumn{2}{|c|}{70 DAT } & \multicolumn{2}{|c|}{30 DAT } & \multicolumn{2}{|c|}{ 50 DAT } & \multicolumn{2}{|c|}{70 DAT } \\
\hline $\mathrm{F}_{0} \mathrm{~S}_{1}$ & 25.20 & $\mathrm{a}$ & 27.87 & $\mathrm{~cd}$ & 28.53 & $\mathrm{~b}$ & 10.80 & $\mathrm{~d}$ & 10.27 & $\mathrm{f}$ & 12.90 & $\mathrm{f}$ \\
\hline $\mathrm{F}_{0} \mathrm{~S}_{2}$ & 26.33 & $\mathrm{a}$ & 28.73 & bc & 30.93 & $\mathrm{ab}$ & 11.53 & $\mathrm{~cd}$ & 10.73 & ef & 13.87 & $\mathrm{e}$ \\
\hline $\mathrm{F}_{0} \mathrm{~S}_{3}$ & 21.20 & $\mathrm{~b}$ & 26.47 & $d$ & 28.20 & $\mathrm{~b}$ & 12.40 & bc & 11.00 & ef & 14.67 & $\mathrm{~d}$ \\
\hline $\mathrm{F}_{1} \mathrm{~S}_{1}$ & 25.13 & a & 29.70 & $a b$ & 31.33 & $\mathrm{ab}$ & 13.20 & $a b$ & 11.93 & def & 15.73 & $\mathrm{c}$ \\
\hline $\mathrm{F}_{1} \mathrm{~S}_{2}$ & 26.20 & $\mathrm{a}$ & 26.73 & $\mathrm{~d}$ & 28.67 & $\mathrm{~b}$ & 12.13 & bc & 12.67 & cde & 14.70 & $\mathrm{~d}$ \\
\hline $\mathrm{F}_{1} \mathrm{~S}_{3}$ & 25.87 & $\mathrm{a}$ & 30.13 & $a b$ & 30.60 & $a b$ & 13.60 & $\mathrm{a}$ & 15.00 & $a b$ & 14.67 & $\mathrm{~d}$ \\
\hline $\mathrm{F}_{2} \mathrm{~S}_{1}$ & 27.47 & $\mathrm{a}$ & 30.47 & $\mathrm{a}$ & 33.13 & $\mathrm{a}$ & 11.67 & $\mathrm{~cd}$ & 13.40 & bcd & 17.13 & $a b$ \\
\hline $\mathrm{F}_{2} \mathrm{~S}_{2}$ & 23.87 & $a b$ & 29.93 & $a b$ & 30.67 & $a b$ & 13.80 & $\mathrm{a}$ & 14.40 & $a b c$ & 16.67 & $\mathrm{~b}$ \\
\hline $\mathrm{F}_{2} \mathrm{~S}_{3}$ & 24.43 & $a b$ & 27.63 & $\mathrm{~cd}$ & 28.60 & $\mathrm{~b}$ & 13.87 & $\mathrm{a}$ & 15.67 & $\mathrm{a}$ & 17.73 & $\mathrm{a}$ \\
\hline $\operatorname{LSD}_{(0.05)}$ & 3.51 & & 1.40 & & 3.98 & & 1.08 & & 1.79 & & 0.75 & \\
\hline $\mathrm{CV}(\%)$ & 8.09 & & 10.67 & & 7.83 & & 8.48 & & 11.55 & & 10.32 & \\
\hline
\end{tabular}

Here, $\mathrm{F}_{0}$ - Control, $\mathrm{F}_{1}$ - Cowdung, $\mathrm{F}_{2}-$ Vermicompost and $\mathrm{S} 1-60 \times 30 \mathrm{~cm}, \mathrm{~S}_{2}-60 \times 40 \mathrm{~cm}, \mathrm{~S} 3-60 \times 50 \mathrm{~cm}$,

\subsection{Number of leaves per plant}

The maximum number of leaves (16.2) at $70 \mathrm{DAT}$ was produced by $\mathrm{F}_{2}$ and the minimum (13.8) was produced by the $F_{0}$ (Figure 2A). The maximum number of leaves (15.7) was obtained from $S_{3}$ while $S_{1}$ gave minimum (15.1) showing significantly different result from other treatments (Figure 2B). It was revealed that with the increases of spacing, number of leaves also increased. Enough space for vertical and horizontal expansion in the optimum spacing that leads for production of maximum number of leaves than the closer spacing. Steingrobe and Schenk (1994) also reported similar results earlier. In combined effect, the highest number of leaves was recorded (17.7) from $F_{2} S_{3}$ and the lowest (12.9) was from $F_{0} S_{1}$ at 70 DAT (Table 3).

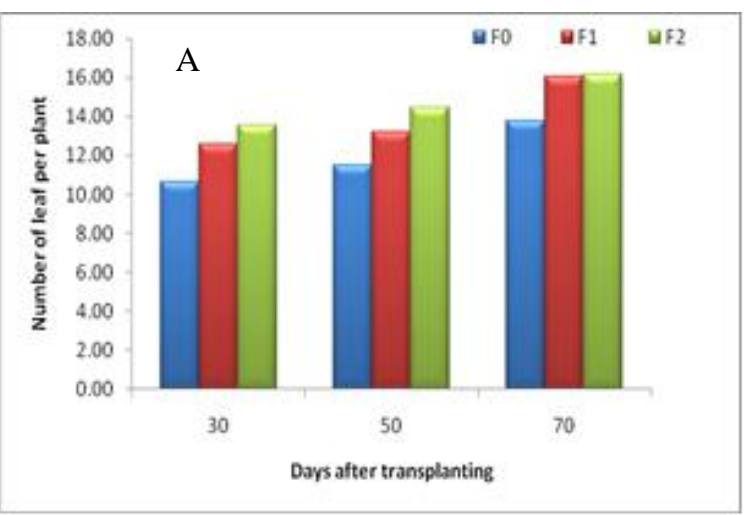

$\mathrm{F}_{0}$ - control, $\mathrm{F}_{1}$-Cowdung, $\mathrm{F}_{2}$ - Vermicompost

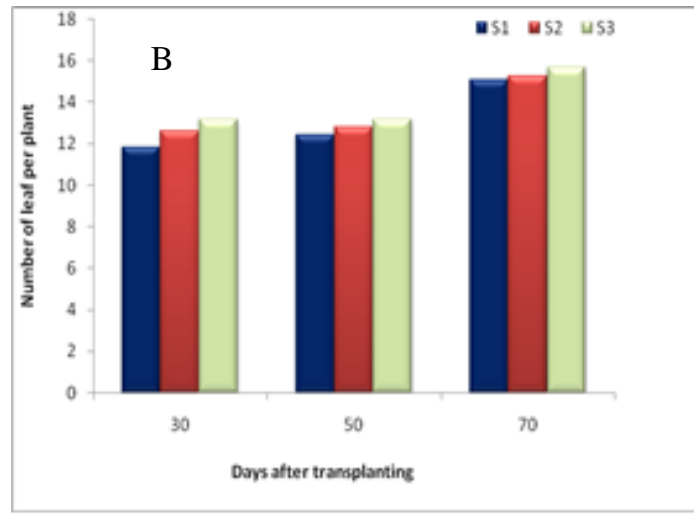

$\mathrm{S}_{1^{-}} 60 \times 30 \mathrm{~cm}, \mathrm{~S}_{2^{-}} 60 \times 40 \mathrm{~cm}, \mathrm{~S}_{3^{-}}-60 \times 50 \mathrm{~cm}$

Figure 2. Effect of organic manure (A) and Spacing (B) on number of leaves per plant of cauliflower at different days after transplanting. 


\subsection{Length of leaf}

The Vermicompost produced longer leaf $(23.7 \mathrm{~cm})$ whereas control gave shorter $(20.8 \mathrm{~cm})$ leaf at 70 DAT (Figure 3A). In addition, Spacing $S_{3}$ produced long leaf $(22.6 \mathrm{~cm})$ and the shorter $(21.4 \mathrm{~cm})$ was in $S_{1}$ at 70 DAT (Figure 3B). It was revealed that with the increases of spacing leaf length showed increasing trend. In case of closer spacing plant compete for light and with the time being leaf length decreases. Sodkowski and Rekowska (2003) reported longest leaf from closer spacing. Again, the longer $(25.7 \mathrm{~cm})$ leaf was obtained from $\mathrm{F}_{2} \mathrm{~S}_{3}$ while shorter $(20.0 \mathrm{~cm})$ was from $\mathrm{F}_{0} \mathrm{~S}_{1}$ at the same DAT (Table 4).

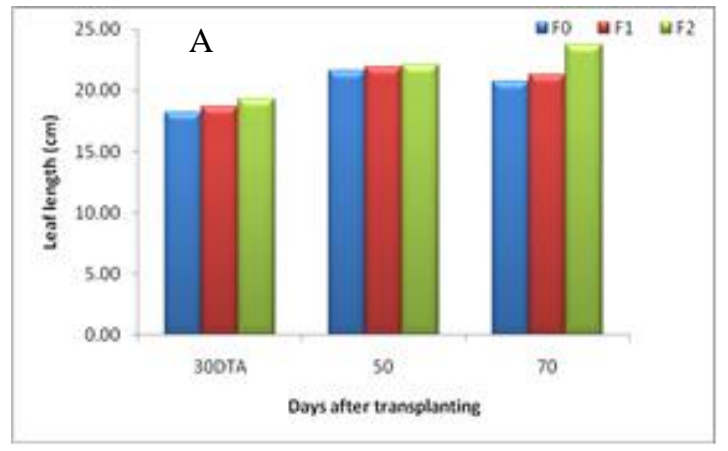

$\mathrm{F}_{0}-$ Control, $\mathrm{F}_{1}-$ Cowdung, $\mathrm{F}_{2}-$ Vermicompost and

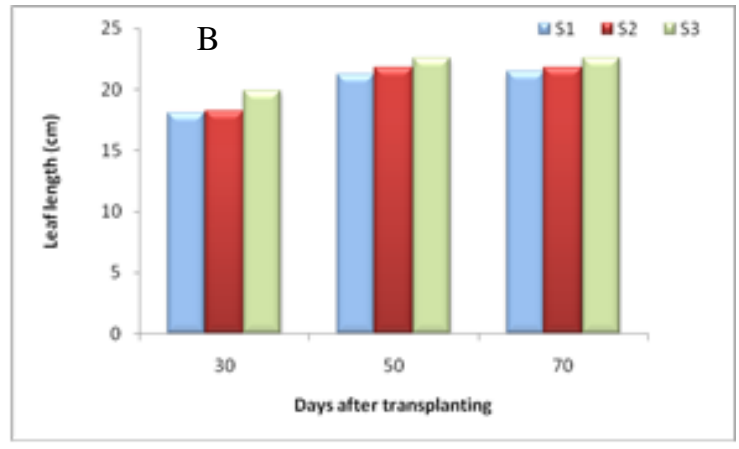

$\mathrm{S}_{1}-60 \times 30 \mathrm{~cm}, \mathrm{~S}_{2}-60 \times 40 \mathrm{~cm}, \mathrm{~S} 3-60 \times 50 \mathrm{~cm}$,

Figure 3. Effect of organic manure (A) and spacing (B) on leaf length of cauliflower at different days after transplanting.

Table 4. Combined effect of organic manure and spacing on leaf length and leaf breadth of cauliflower.

\begin{tabular}{|c|c|c|c|c|c|c|c|c|c|c|c|c|}
\hline \multirow{2}{*}{ Treatment } & \multicolumn{6}{|c|}{ Leaf length $(\mathrm{cm})$} & \multicolumn{6}{|c|}{ Leaf breadth (cm) } \\
\hline & \multicolumn{2}{|l|}{30 DAT } & \multicolumn{2}{|c|}{50 DAT } & \multicolumn{2}{|c|}{70 DAT } & \multicolumn{2}{|c|}{ 30 DAT } & \multicolumn{2}{|c|}{50 DAT } & \multicolumn{2}{|c|}{70 DAT } \\
\hline $\mathrm{F}_{0} \mathrm{~S}_{1}$ & 16.27 & $\mathrm{c}$ & 19.80 & $\mathrm{e}$ & 20.03 & $\mathrm{c}$ & 9.27 & $\mathrm{~b}$ & 10.57 & c & 10.73 & $\mathrm{c}$ \\
\hline $\mathrm{F}_{0} \mathrm{~S}_{2}$ & 18.93 & $\mathrm{bc}$ & 21.97 & $\mathrm{bc}$ & 21.17 & $\mathrm{bc}$ & 11.23 & $a b$ & 11.50 & $a b$ & 12.60 & $a b$ \\
\hline $\mathrm{F}_{0} \mathrm{~S}_{3}$ & 18.57 & $\mathrm{bc}$ & 23.00 & $a b$ & 22.07 & $\mathrm{bc}$ & 10.47 & $a b$ & 10.80 & $\mathrm{bc}$ & 12.30 & $a b c$ \\
\hline $\mathrm{F}_{1} \mathrm{~S}_{1}$ & 18.43 & $\mathrm{bc}$ & 21.33 & $\mathrm{~cd}$ & 20.60 & $\mathrm{c}$ & 9.50 & $\mathrm{~b}$ & 11.37 & $a b c$ & 10.77 & $\mathrm{c}$ \\
\hline $\mathrm{F}_{1} \mathrm{~S}_{2}$ & 18.30 & $\mathrm{bc}$ & 20.40 & de & 21.43 & $\mathrm{bc}$ & 9.80 & $a b$ & 10.67 & $\mathrm{bc}$ & 10.93 & $\mathrm{bc}$ \\
\hline $\mathrm{F}_{1} \mathrm{~S}_{3}$ & 19.40 & $\mathrm{~b}$ & 20.60 & de & 20.80 & $\mathrm{bc}$ & 11.00 & $a b$ & 12.13 & $\mathrm{a}$ & 12.37 & $a b c$ \\
\hline $\mathrm{F}_{2} \mathrm{~S}_{1}$ & 17.13 & $\mathrm{bc}$ & 22.60 & $\mathrm{bc}$ & 21.40 & $\mathrm{bc}$ & 9.90 & $a b$ & 11.43 & $a b c$ & 12.37 & $a b c$ \\
\hline $\mathrm{F}_{2} \mathrm{~S}_{2}$ & 17.50 & $\mathrm{bc}$ & 23.00 & $a b$ & 24.07 & $a b$ & 10.50 & $a b$ & 11.50 & $a b$ & 12.77 & $\mathrm{a}$ \\
\hline $\mathrm{F}_{2} \mathrm{~S}_{3}$ & 24.03 & $\mathrm{a}$ & 24.13 & $\mathrm{a}$ & 25.67 & $\mathrm{a}$ & 11.57 & $\mathrm{a}$ & 12.17 & $\mathrm{a}$ & 13.73 & $\mathrm{a}$ \\
\hline $\operatorname{LSD}_{(0.05)}$ & 2.56 & & 1.27 & & 3.06 & & 1.82 & & 0.82 & & 1.58 & \\
\hline $\mathrm{CV}(\%)$ & 10.91 & & 8.05 & & 10.80 & & 10.49 & & 9.17 & & 9.11 & \\
\hline
\end{tabular}

$\mathrm{F}_{0^{-}}$Control, $\mathrm{F}_{1}-$ Cowdung, $\mathrm{F}_{2}-$ Vermicompost and $\mathrm{S}_{1}-60 \times 30 \mathrm{~cm}, \mathrm{~S}_{2}-60 \times 40 \mathrm{~cm}, \mathrm{~S} 3-60 \times 50 \mathrm{~cm}$,

Breadth of leaf per plant

Among the manures, $F_{2}$ produced the widest $(13.0 \mathrm{~cm})$ leaf while $F_{0}$ produced narrowest leaf $(11.4 \mathrm{~cm})$ at 70 DAT (Fig. 4A). The Breadth of leaf recorded at different days was significantly influenced by spacing where $\mathrm{S}_{3}$ produced broader leaf $(12.3 \mathrm{~cm})$ and the narrower $(11.7 \mathrm{~cm})$ was in $S_{1}$ at 70 DAT (Fig. 4B). It was revealed that with the increases of spacing leaf breath showed increasing trend. In case of closer spacing plant compete for light and with the time being leaf breath decreases. In combination effect, numerically the widest $(13.7 \mathrm{~cm})$ was obtained from the $\mathrm{F}_{2} \mathrm{~S}_{3}$ and the narrowest $\left(10.7 \mathrm{~cm}\right.$ ) was in $\mathrm{F}_{0} \mathrm{~S}_{1}$ at 70 DAT (Table 4). 


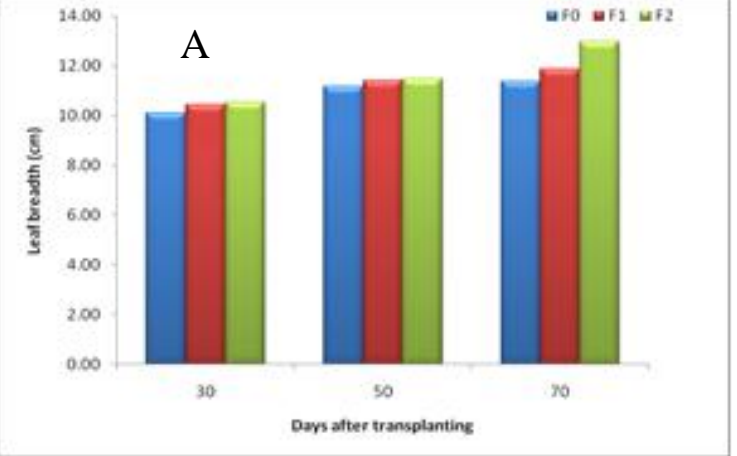

$\mathrm{F}_{0^{-}}$Control, $\mathrm{F}_{1}$-Cowdung, $\mathrm{F}_{2}$-Vermicompost and

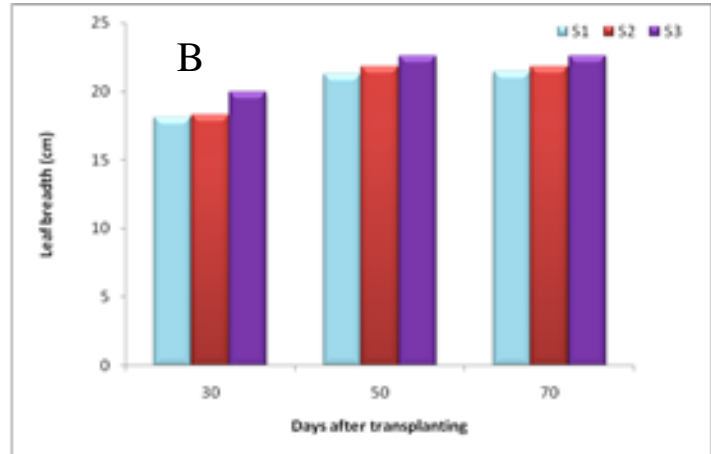

$\mathrm{S}_{1}-60 \times 30 \mathrm{~cm}, \mathrm{~S}_{2}-60 \times 40 \mathrm{~cm}, \mathrm{~S} 3-60 \times 50 \mathrm{~cm}$,

Figure 4. Effect of organic manuring (A) and spacing (B) on breath of leaf of cauliflower at different days after transplanting.

\subsection{Fresh weight of leaves per plant (g)}

The maximum fresh weight $(277.2 \mathrm{~g})$ was observed in $\mathrm{F}_{2}$ and the minimum $(188.3 \mathrm{~g})$ was in $\mathrm{F}_{0}$ at 70 DAT (Figure 5A). Among the organic manure vermicompost was more effective than other organic manure. Besides, in case of spacing, $S_{3}$ produced maximum fresh weight $(284.5 \mathrm{~g})$ and the $S_{1}(204.4 \mathrm{~g})$ gave the minimum at 70 DAT (Figure 5B). It was revealed that with the increases of spacing fresh weight of leaves per plant showed increasing trend. In case of wider spacing plant receive enough light and nutrients which leads to attain maximum fresh weight of leaves per plant. Similar result was also observed by Sharma et al. (2001). In combined effect, the highest (348.2 g) and lowest (150.00 g) weight was observed in $\mathrm{F}_{2} \mathrm{~S}_{3}$ and $\mathrm{F}_{0} \mathrm{~S}_{1}$ at 70 DAT (Table 5).

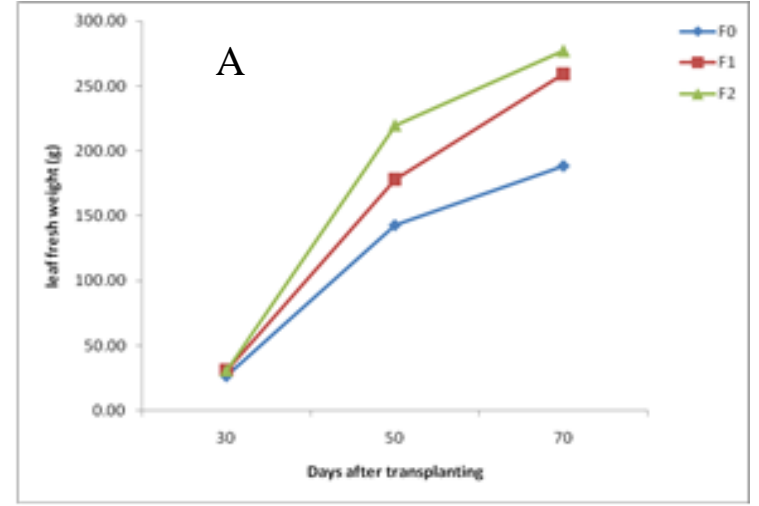

$\mathrm{F}_{0^{-}}$Control, $\mathrm{F}_{1}$ - Cowdung, $\mathrm{F}_{2}-$ Vermicompost and

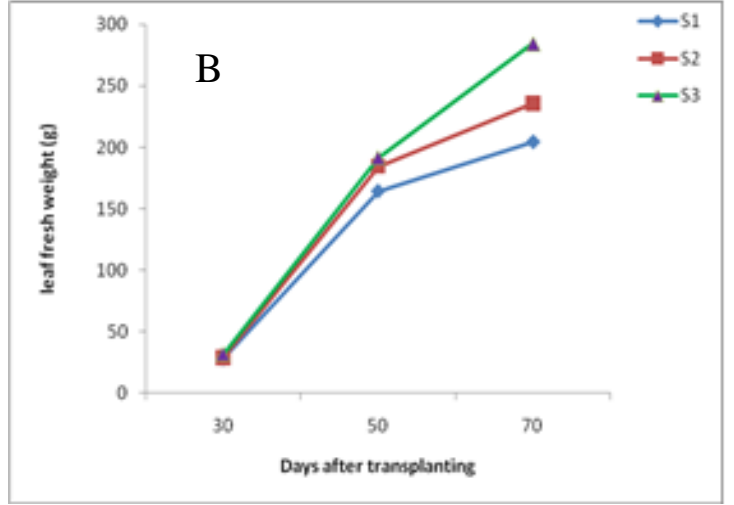

$\mathrm{S}_{1}-60 \times 30 \mathrm{~cm}, \mathrm{~S}_{2^{-}} 60 \times 40 \mathrm{~cm}, \mathrm{~S}_{3^{-}} 60 \times 50 \mathrm{~cm}$,

Figure 5. Effect of organic manure (A) and spacing (B) on fresh weight of leaf per plant of cauliflower.

Table 5. Combined effect of organic manure and spacing on fresh weight and dry weight of leaf per plant of cauliflower.

\begin{tabular}{|c|c|c|c|c|c|c|c|c|c|c|c|c|}
\hline \multirow{2}{*}{ Treatment } & \multicolumn{6}{|c|}{ Fresh weight (g) at } & \multicolumn{6}{|c|}{ Dry weight of leaf (g) at } \\
\hline & 30 DAT & & 50 DAT & & 70 DAT & & $30 \mathbf{D A}^{\prime}$ & & $50 \mathrm{DA}$ & & 70 DA & \\
\hline $\mathrm{F}_{0} \mathrm{~S}_{1}$ & 24.73 & $\mathrm{c}$ & 122.00 & $\mathrm{~b}$ & 150.00 & $\mathrm{c}$ & 12.41 & $\mathrm{c}$ & 25.6 & $\mathrm{f}$ & 45.55 & $\mathrm{e}$ \\
\hline $\mathrm{F}_{0} \mathrm{~S}_{2}$ & 25.37 & $\mathrm{bc}$ & 131.80 & $a b$ & 182.70 & bc & 12.95 & $\mathrm{bc}$ & 35.94 & ef & 59.97 & $\mathrm{~d}$ \\
\hline $\mathrm{F}_{0} \mathrm{~S}_{3}$ & 30.80 & $a b c$ & 174.60 & $\mathrm{ab}$ & 232.30 & $a b c$ & 16.34 & $\mathrm{a}$ & 60.43 & $\mathrm{~cd}$ & 98.27 & bc \\
\hline $\mathrm{F}_{1} \mathrm{~S}_{1}$ & 30.93 & $\mathrm{ab}$ & 182.70 & $\mathrm{ab}$ & 242.10 & $a b c$ & 15.70 & $a b$ & 47.26 & de & 71.95 & $\mathrm{~d}$ \\
\hline $\mathrm{F}_{1} \mathrm{~S}_{2}$ & 31.17 & $a b$ & 153.00 & $a b$ & 196.30 & $a b c$ & 16.20 & $a b$ & 63.89 & $\mathrm{c}$ & 86.49 & $\mathrm{c}$ \\
\hline $\mathrm{F}_{1} \mathrm{~S}_{3}$ & 30.43 & $a b c$ & 198.40 & $a b$ & 233.20 & $a b c$ & 15.71 & $a b$ & 69.83 & $\mathrm{bc}$ & 89.84 & $\mathrm{c}$ \\
\hline $\mathrm{F}_{2} \mathrm{~S}_{1}$ & 31.30 & $a b$ & 202.00 & $a b$ & 322.70 & $a b$ & 16.01 & $a b$ & 71.52 & $\mathrm{bc}$ & 110.5 & $\mathrm{~b}$ \\
\hline $\mathrm{F}_{2} \mathrm{~S}_{2}$ & 28.10 & $a b c$ & 218.70 & $a b$ & 266.70 & $a b c$ & 14.19 & $a b c$ & 80.46 & $a b$ & 135.6 & $\mathrm{a}$ \\
\hline $\mathrm{F}_{2} \mathrm{~S}_{3}$ & 33.37 & $\mathrm{a}$ & 238.80 & $\mathrm{a}$ & 348.20 & $\mathrm{a}$ & 17.33 & $\mathrm{a}$ & 91.07 & $\mathrm{a}$ & 146.6 & $\mathrm{a}$ \\
\hline $\operatorname{LSD}_{(0.05)}$ & 5.53 & & 95.92 & & 145.00 & & 2.98 & & 14.58 & & 14.43 & \\
\hline $\mathrm{CV}(\%)$ & 10.75 & & 14.68 & & 11.31 & & 11.89 & & 14.45 & & 11.31 & \\
\hline
\end{tabular}

$\mathrm{F}_{0^{-}}$Control, $\mathrm{F}_{1}$ - Cowdung, $\mathrm{F}_{2}-$ Vermicompost and $\mathrm{S} 1-60 \times 30 \mathrm{~cm}, \mathrm{~S}_{2^{-}} 60 \times 40 \mathrm{~cm}, \mathrm{~S} 3-60 \times 50 \mathrm{~cm}$, 
3.5. Dry weight of leaves per plant (g)

The maximum dry weight $(112.0 \mathrm{~g})$ was observed in $\mathrm{F}_{2}$ and the minimum $(67.93 \mathrm{~g})$ was in the $\mathrm{F}_{0}$ at 70 DAT (Figure $6 \mathrm{~A}$ ). Spacing $\mathrm{S}_{3}$ contributed maximum dry weight of $114 \mathrm{~g}$ and the minimum $(75.99 \mathrm{~g})$ was in $\mathrm{S}_{1}$ at 70 DAT (Figure $6 \mathrm{~B}$ ). It was revealed that with the increases of spacing dry weight per plant showed increasing trend because of less competition for nutrients among the plants during growth stages. The interaction effects of organic manure and plant spacing were significant in respect of dry weight per plant. The highest (146.6 g) and lowest (45.55 g) were observed in the $\mathrm{F}_{2} \mathrm{~S}_{3}$ and $\mathrm{F}_{0} \mathrm{~S}_{1}$, respectively at 70 DAT (Table 5).

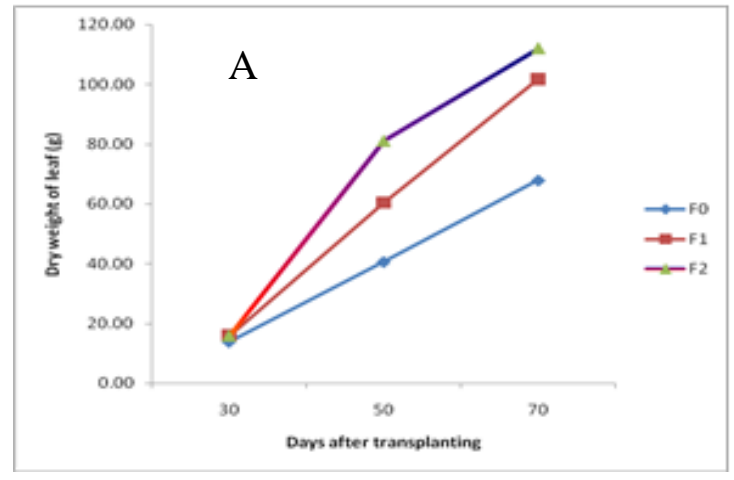

$\mathrm{F}_{0}$-Control, $\mathrm{F}_{1}$ - Cowdung, $\mathrm{F}_{2}-$ Vermicompost and

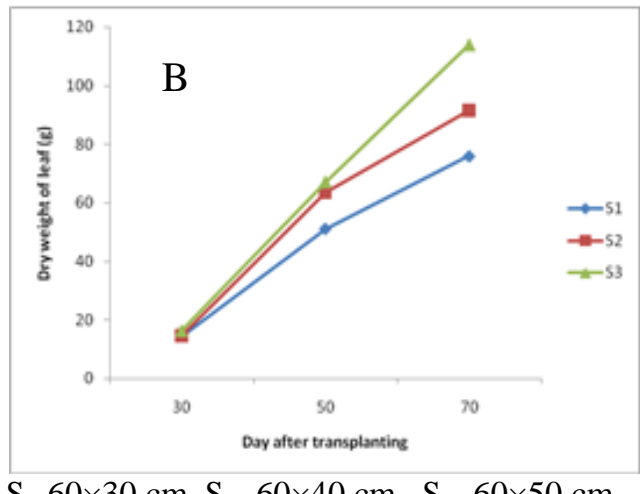

$\mathrm{S}_{1}-60 \times 30 \mathrm{~cm}, \mathrm{~S}_{2}-60 \times 40 \mathrm{~cm}, \mathrm{~S}_{3}-60 \times 50 \mathrm{~cm}$,

Figure 6. Effect of organic manure (A) and spacing (B) on dry weight of leaf per plant of cauliflower.

\subsection{Stem diameter}

Vermicompost produced the highest stem diameter $(1.85 \mathrm{~cm})$ and control treatment produced lowest $(1.8 \mathrm{~cm})$ at 70 DAT (Figure7A). The Stem diameter counted at different days was significantly influenced by spacing where $\mathrm{S}_{3}$ produced maximum $(1.89 \mathrm{~cm})$ and $\mathrm{S}_{1}$ showed the minimum $(1.73 \mathrm{~cm})$ (Figure $\left.7 \mathrm{~B}\right)$. Again, numerically the highest diameter of stem $(1.93 \mathrm{~cm})$ was obtained from $\mathrm{F}_{2} \mathrm{~S}_{3}$ and the minimum $(1.72 \mathrm{~cm})$ was in $\mathrm{F}_{0} \mathrm{~S}_{1}$ at 70 DAT (Table 6).

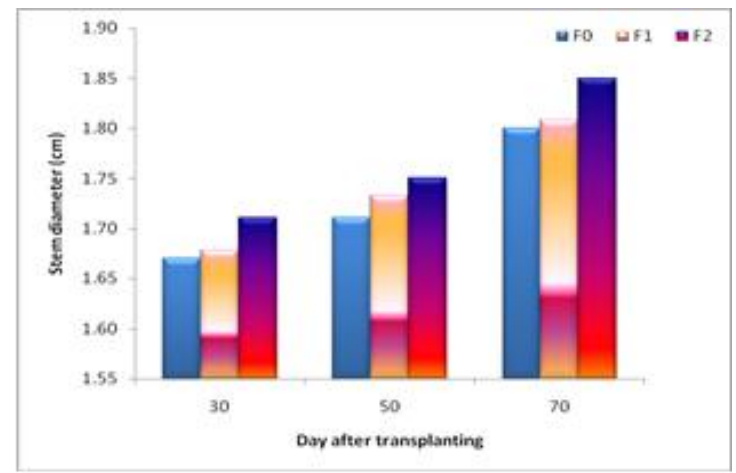

$\mathrm{F}_{0^{-}}$Control, $\mathrm{F}_{1}$ - Cowdung, $\mathrm{F}_{2}-$ Vermicompost and

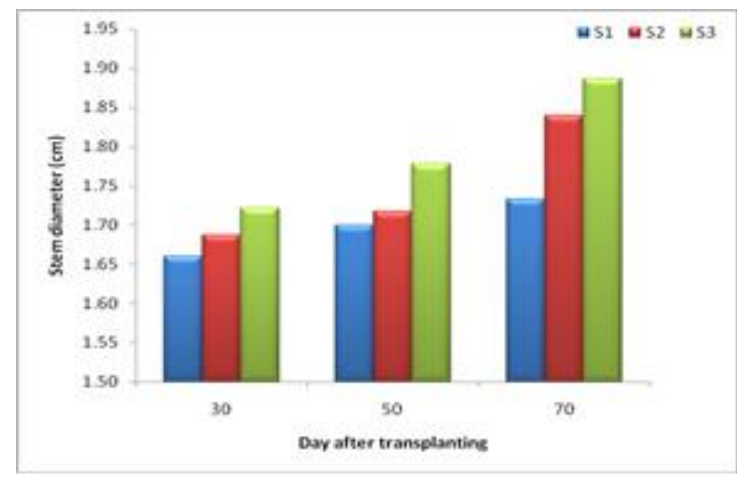

$\mathrm{S}_{1^{-}} 60 \times 30 \mathrm{~cm}, \mathrm{~S}_{2^{-}} 60 \times 40 \mathrm{~cm}, \mathrm{~S}_{3^{-}} 60 \times 50 \mathrm{~cm}$,

Figure 7. Effect of organic manure on stem diameter of cauliflower.

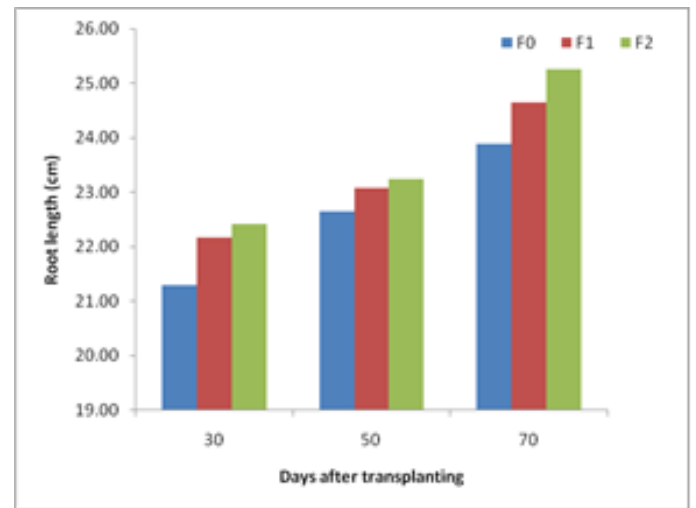

$\mathrm{F}_{0^{-}}$Control, $\mathrm{F}_{1}$-Cowdung, $\mathrm{F}_{2}$ - Vermicompost and

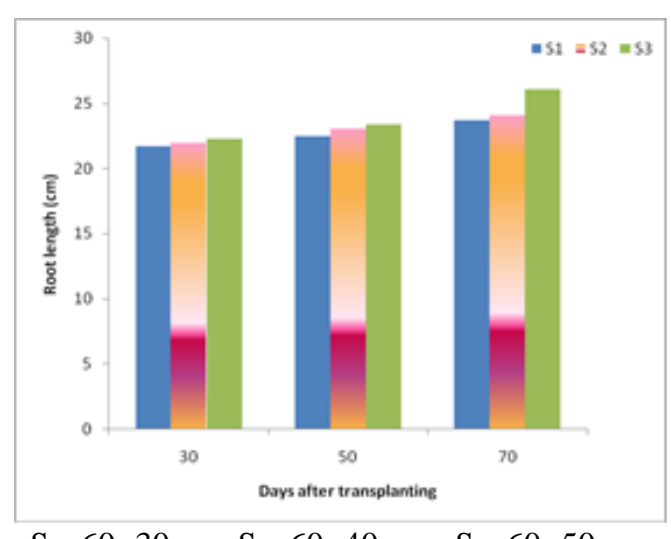

$\mathrm{S}_{1^{-}} 60 \times 30 \mathrm{~cm}, \mathrm{~S}_{2^{-}} 60 \times 40 \mathrm{~cm}, \mathrm{~S}_{3^{-}} 60 \times 50 \mathrm{~cm}$,

Figure 8. Effect of organic manure and spacing on root length of cauliflower. 
Table 6. Combined effect of organic manure and spacing stem diameter and root length of cauliflower.

\begin{tabular}{|c|c|c|c|c|c|c|c|c|c|c|c|c|}
\hline \multirow{3}{*}{$\begin{array}{l}\text { Treatment } \\
\mathrm{F}_{0} \mathrm{~S}_{1}\end{array}$} & \multicolumn{6}{|c|}{ Stem Diameter $(\mathrm{cm})$ at } & \multicolumn{6}{|c|}{ Root length $(\mathrm{cm})$ at } \\
\hline & \multicolumn{2}{|l|}{30 DAT } & \multicolumn{2}{|c|}{50 DAT } & \multicolumn{2}{|c|}{70 DAT } & \multicolumn{2}{|c|}{30 DAT } & \multicolumn{2}{|c|}{50 DAT } & \multicolumn{2}{|c|}{70 DAT } \\
\hline & 1.62 & $\mathrm{bc}$ & 1.67 & $\mathrm{bc}$ & 1.72 & $\mathrm{c}$ & 21.50 & $\mathrm{bc}$ & 22.17 & $\mathrm{~b}$ & 23.17 & $a b$ \\
\hline $\mathrm{F}_{0} \mathrm{~S}_{2}$ & 1.70 & $\mathrm{~b}$ & 1.70 & $\mathrm{bc}$ & 1.83 & $\mathrm{ab}$ & 23.00 & $a b$ & 24.37 & $a b$ & 24.00 & $\mathrm{ab}$ \\
\hline $\mathrm{F}_{0} \mathrm{~S}_{3}$ & 1.70 & $\mathrm{~b}$ & 1.80 & $a b$ & 1.86 & $\mathrm{ab}$ & 22.00 & $\mathrm{bc}$ & 22.67 & $a b$ & 24.33 & $\mathrm{ab}$ \\
\hline $\mathrm{F}_{1} \mathrm{~S}_{1}$ & 1.63 & $\mathrm{c}$ & 1.70 & $\mathrm{bc}$ & 1.73 & $\mathrm{~cd}$ & 21.40 & $\mathrm{bc}$ & 23.22 & $a b$ & 23.33 & $\mathrm{~b}$ \\
\hline $\mathrm{F}_{1} \mathrm{~S}_{2}$ & 1.70 & $\mathrm{~b}$ & 1.75 & $\mathrm{~b}$ & 1.80 & $\mathrm{bc}$ & 21.33 & $\mathrm{bc}$ & 22.44 & $a b$ & 24.83 & $a b$ \\
\hline $\mathrm{F}_{1} \mathrm{~S}_{3}$ & 1.67 & $\mathrm{bc}$ & 1.70 & $\mathrm{bc}$ & 1.88 & $\mathrm{ab}$ & 21.17 & $\mathrm{c}$ & 22.28 & $\mathrm{ab}$ & 24.33 & $\mathrm{ab}$ \\
\hline $\mathrm{F}_{2} \mathrm{~S}_{1}$ & 1.70 & $\mathrm{~b}$ & 1.73 & $\mathrm{bc}$ & 1.73 & $\mathrm{~cd}$ & 21.87 & $\mathrm{bc}$ & 22.50 & $a b$ & 26.10 & $\mathrm{ab}$ \\
\hline $\mathrm{F}_{2} \mathrm{~S}_{2}$ & 1.67 & $\mathrm{bc}$ & 1.70 & $\mathrm{bc}$ & 1.87 & $\mathrm{ab}$ & 21.50 & $\mathrm{bc}$ & 22.43 & $a b$ & 24.50 & $\mathrm{ab}$ \\
\hline $\mathrm{F}_{2} \mathrm{~S}_{3}$ & 1.80 & $\mathrm{a}$ & 1.83 & $\mathrm{a}$ & 1.93 & $\mathrm{a}$ & 23.90 & $\mathrm{a}$ & 24.80 & $\mathrm{a}$ & 27.78 & $\mathrm{a}$ \\
\hline $\operatorname{LSD}_{(0.05)}$ & 0.08 & & 0.08 & & 0.08 & & 1.53 & & 1.59 & & 3.45 & \\
\hline CV (\%) & 6.04 & & 7.65 & & 7.50 & & 9.99 & & 9.40 & & 11.11 & \\
\hline
\end{tabular}

$\mathrm{F}_{0^{-}}$Control, $\mathrm{F}_{1^{-}}$Cowdung, $\mathrm{F}_{2}$-Vermicompost and $\mathrm{S}_{1^{-}}-60 \times 30 \mathrm{~cm}, \mathrm{~S}_{2}-60 \times 40 \mathrm{~cm}, \mathrm{~S} 3-60 \times 50 \mathrm{~cm}$,

\subsection{Root length}

Vermicompost produced the highest root length of $25.3 \mathrm{~cm}$ and control produced the lowest of $23.9 \mathrm{~cm}$ at 70 DAT (Figure 8A). Besides, $S_{3}$ produced maximum $(26.1 \mathrm{~cm})$ and the minimum $(23.7 \mathrm{~cm})$ was in $S_{1}$ at 70 DAT (Figure 8B). In combined effect, the highest root length $\left(27.8 \mathrm{~cm}\right.$ ) was obtained from $\mathrm{F}_{2} \mathrm{~S}_{3}$ and the minimum $(23.2 \mathrm{~cm})$ was in $\mathrm{F}_{0} \mathrm{~S}_{1}$ at 70 DAT (Table 6).

\subsection{Curd height}

During the period of plant growth the longest curd $(8.9 \mathrm{~cm})$ was observed in $\mathrm{F}_{2}$ while shortest $(8.0 \mathrm{~cm})$ was in $\mathrm{F}_{0}$ at 70 DAT (Table 7). Organic manure ensures available essential nutrients for the plant for that organic manure gave the highest pure curd height compare to control. No significant variation on pure curd height of cauliflower was shown due to different plant spacing at 50,60 and 70 DAT (Table 7). The combined effect of organic manure and spacing at different days after transplanting was also significant. The maximum pure curd height $(9.1 \mathrm{~cm})$ was found from $\mathrm{F}_{2} \mathrm{~S}_{1}$ and the lowest $\left(7.7 \mathrm{~cm}\right.$ ) was from $\mathrm{F}_{0} \mathrm{~S}_{1}$ at 70 DAT (Table 7).

\subsection{Diameter of curd}

Among the organic manures, vermicompost produced the highest diameter $(14.3 \mathrm{~cm})$ and control produced the lowest $\left(13.0 \mathrm{~cm}\right.$ ) at 70 DAT (Table 7). The diameter of curd was significantly influenced by spacing where $\mathrm{S}_{3}$ produced maximum $(14.4 \mathrm{~cm})$ and minimum $(12.9 \mathrm{~cm})$ was in $S_{1}$ at 70 DAT (Table 7). On the contrary, in combination, the highest diameter $(15.2 \mathrm{~cm})$ was obtained from $\mathrm{F}_{2} \mathrm{~S}_{3}$ and the minimum $(11.8 \mathrm{~cm})$ was in $\mathrm{F}_{0} \mathrm{~S}_{1}$ (Table 7).

\subsection{Curd weight}

The maximum curd weight $(360.3 \mathrm{~g})$ was recorded from $\mathrm{F}_{2}$, while the minimum $(231.9 \mathrm{~g})$ was from $\mathrm{F}_{0}$ at 70 DAT (Table 8). On the other hand, spacing $S_{3}$ gave maximum curd weight (365.4 g) and $S_{1}$ showed the minimum (265.1 g) at 70 DAT (Table 8). It was revealed that with the increases of spacing individual weight per plant increased (Plate 1). In combination, the highest (408.3 g) and the lowest (185.8 $\mathrm{g})$ curd weight was observed in $\mathrm{F}_{2} \mathrm{~S}_{3}$ and $\mathrm{F}_{0} \mathrm{~S}_{1}$, respectively (Table 8). 
Asian J. Med. Biol. Res. 2016, 2 (2)

Table 7. Effect of organic manure and spacing on Curd height and curd diameter summer cauliflower.

\begin{tabular}{|c|c|c|c|c|c|c|c|c|c|c|c|c|}
\hline \multirow[t]{2}{*}{ Treatment } & \multicolumn{6}{|c|}{ Curd height $(\mathrm{cm})$ at } & \multicolumn{6}{|c|}{ Curd diameter $(\mathrm{cm})$ at } \\
\hline & \multicolumn{2}{|c|}{ 50 DAT } & \multicolumn{2}{|c|}{ 60 DAT } & \multicolumn{2}{|c|}{70 DAT } & \multicolumn{2}{|c|}{ 50 DAT } & \multicolumn{2}{|c|}{ 60 DAT } & \multicolumn{2}{|c|}{70 DAT } \\
\hline \multicolumn{13}{|c|}{ Organic manures } \\
\hline $\mathrm{F}_{0}$ & 7.56 & $\mathrm{ab}$ & 7.97 & $\mathrm{~b}$ & 8.04 & $\mathrm{~b}$ & 7.70 & $\mathrm{~b}$ & 8.27 & $\mathrm{~b}$ & 13.02 & $\mathrm{c}$ \\
\hline$F_{1}$ & 7.89 & $a b$ & 8.16 & $a b$ & 8.49 & $a b$ & 7.72 & $\mathrm{~b}$ & 8.43 & $\mathrm{~b}$ & 13.67 & $\mathrm{~b}$ \\
\hline $\mathrm{F}_{2}$ & 8.11 & $\mathrm{a}$ & 8.46 & $\mathrm{a}$ & 8.91 & $\mathrm{a}$ & 7.83 & $\mathrm{a}$ & 8.73 & $\mathrm{a}$ & 14.25 & $\mathrm{a}$ \\
\hline $\operatorname{LSD}_{(0.05)}$ & 1.22 & & 0.46 & & 0.84 & & 0.05 & & 0.19 & & 0.42 & \\
\hline $\mathrm{CV}(\%)$ & 6.03 & & 4.99 & & 9.63 & & 3.28 & & 9.02 & & 13.17 & \\
\hline \multicolumn{13}{|c|}{ Spacing } \\
\hline $\mathrm{S}_{1}$ & 7.72 & $a b$ & 8.11 & $a b$ & 8.38 & $a b$ & 7.69 & $a b$ & 8.36 & $a b$ & 12.87 & $a b$ \\
\hline $\mathrm{S}_{2}$ & 7.89 & $a b$ & 8.13 & $a b$ & 8.53 & $\mathrm{a}$ & 7.73 & $\mathrm{ab}$ & 8.43 & $a b$ & 13.62 & $a b$ \\
\hline $\mathrm{S}_{3}$ & 7.94 & $\mathrm{a}$ & 8.36 & $\mathrm{a}$ & 8.53 & $\mathrm{a}$ & 7.83 & $\mathrm{a}$ & 8.65 & $\mathrm{a}$ & 14.44 & $\mathrm{a}$ \\
\hline $\operatorname{LSD}_{(0.05)}$ & 1.67 & & 0.38 & & 0.91 & & 0.272 & & 0.248 & & 1.19 & \\
\hline $\mathrm{CV}(\%)$ & 6.03 & & 4.99 & & 9.63 & & 3.28 & & 9.02 & & 13.17 & \\
\hline \multicolumn{13}{|c|}{ Combination } \\
\hline $\mathrm{F}_{0} \mathrm{~S}_{1}$ & 7.17 & $\mathrm{bc}$ & 7.74 & $\mathrm{~cd}$ & 7.70 & $\mathrm{~d}$ & 7.57 & $\mathrm{~d}$ & 7.95 & $\mathrm{~d}$ & 11.83 & $\mathrm{~g}$ \\
\hline $\mathrm{F}_{0} \mathrm{~S}_{2}$ & 7.67 & $a b$ & 8.00 & $\mathrm{bc}$ & 8.27 & $\mathrm{bc}$ & 7.70 & bcd & 8.30 & $\mathrm{c}$ & 12.67 & $\mathrm{f}$ \\
\hline $\mathrm{F}_{0} \mathrm{~S}_{3}$ & 7.67 & $a b$ & 8.00 & $\mathrm{bc}$ & 8.47 & $\mathrm{bc}$ & 7.80 & $a b$ & 8.57 & $\mathrm{~b}$ & 13.11 & ef \\
\hline $\mathrm{F}_{1} \mathrm{~S}_{1}$ & 7.67 & $a b$ & 7.74 & $\mathrm{bc}$ & 8.17 & $\mathrm{c}$ & 7.83 & $a b$ & 8.41 & $\mathrm{bc}$ & 14.89 & $a b$ \\
\hline $\mathrm{F}_{1} \mathrm{~S}_{2}$ & 7.67 & $a b$ & 8.57 & $a b$ & 8.72 & $a b$ & 7.80 & $a b$ & 8.40 & $\mathrm{bc}$ & 14.20 & $\mathrm{bc}$ \\
\hline $\mathrm{F}_{1} \mathrm{~S}_{3}$ & 8.33 & $a b$ & 8.73 & $a b$ & 8.97 & $a b$ & 7.87 & $a b$ & 8.80 & $a b$ & 13.67 & cde \\
\hline $\mathrm{F}_{2} \mathrm{~S}_{1}$ & 7.83 & $a b$ & 7.90 & $\mathrm{bc}$ & 8.72 & $a b$ & 7.73 & $a b c$ & 8.57 & $\mathrm{~b}$ & 13.28 & def \\
\hline $\mathrm{F}_{2} \mathrm{~S}_{2}$ & 8.33 & $a b$ & 8.00 & $\mathrm{bc}$ & 8.27 & $\mathrm{bc}$ & 7.60 & $\mathrm{~cd}$ & 8.33 & $\mathrm{c}$ & 14.00 & $\mathrm{~cd}$ \\
\hline $\mathrm{F}_{2} \mathrm{~S}_{3}$ & 8.34 & $\mathrm{a}$ & 9.08 & $\mathrm{a}$ & 9.10 & $\mathrm{a}$ & 7.90 & $\mathrm{a}$ & 8.99 & $\mathrm{a}$ & 15.17 & $\mathrm{a}$ \\
\hline $\operatorname{LSD}_{(0.05)}$ & 0.82 & & 0.58 & & 0.45 & & 0.13 & & 0.21 & & 0.80 & \\
\hline $\mathrm{CV}(\%)$ & 6.03 & & 4.99 & & 9.63 & & 3.28 & & 9.02 & & 13.17 & \\
\hline
\end{tabular}

$\mathrm{F}_{0^{-}}$Control, $\mathrm{F}_{1}$ - Cowdung, $\mathrm{F}_{2}$ - Vermicompost and $\mathrm{S} 1-60 \times 30 \mathrm{~cm}, \mathrm{~S}_{2^{-}} 60 \times 40 \mathrm{~cm}, \mathrm{~S} 3-60 \times 50 \mathrm{~cm}$,

Table 8. Effect of organic manure and spacing on Curd weight of cauliflower.

\begin{tabular}{|c|c|c|c|c|c|c|c|}
\hline \multirow{2}{*}{ Treatment } & \multicolumn{7}{|c|}{ Curd weight (g) } \\
\hline & \multicolumn{2}{|c|}{50 DAT } & \multicolumn{2}{|c|}{60 DAT } & \multicolumn{2}{|c|}{70 DAT } & \\
\hline \multicolumn{8}{|l|}{ Manures } \\
\hline $\mathrm{F}_{0}$ & $\mathrm{c}$ & 105.7 & $\mathrm{~b}$ & 183.3 & $\mathrm{c}$ & 231.9 & $\mathrm{~d}$ \\
\hline$F_{1}$ & $\mathrm{~b}$ & 122.3 & $a b$ & 217.1 & $\mathrm{cb}$ & 346.20 & $a b$ \\
\hline $\mathrm{F}_{2}$ & $\mathrm{a}$ & 123.4 & $\mathrm{a}$ & 276.5 & $\mathrm{a}$ & 360.3 & $\mathrm{a}$ \\
\hline $\operatorname{LSD}_{(0.05)}$ & & 1.52 & & 29.29 & & 27.4 & \\
\hline $\mathrm{CV}(\%)$ & & 10.16 & & 10.89 & & 8.40 & \\
\hline \multicolumn{8}{|l|}{ Spacing } \\
\hline $\mathrm{S}_{1}$ & & 114.7 & $\mathrm{~b}$ & 191.7 & $\mathrm{~b}$ & 265.1 & $\mathrm{c}$ \\
\hline $\mathrm{S}_{2}$ & & 115.9 & $a b$ & 249.8 & $a b$ & 307.8 & $\mathrm{~b}$ \\
\hline $\mathrm{S}_{3}$ & & 120.8 & $\mathrm{a}$ & 235.4 & $\mathrm{a}$ & 365.4 & $\mathrm{a}$ \\
\hline $\operatorname{LSD}_{(0.05)}$ & & 1.036 & & 7.548 & & 27.63 & \\
\hline $\mathrm{CV}(\%)$ & & 10.16 & & 10.89 & & 8.40 & \\
\hline \multicolumn{8}{|l|}{ Combination } \\
\hline$\overline{F_{0} S_{1}}$ & & 102.4 & $\mathrm{~d}$ & 145.4 & f & 185.8 & $\mathrm{~g}$ \\
\hline $\mathrm{F}_{0} \mathrm{~S}_{2}$ & & 104.3 & $\mathrm{~cd}$ & 190.4 & e & 239.9 & $\mathrm{f}$ \\
\hline $\mathrm{F}_{0} \mathrm{~S}_{3}$ & & 110.5 & bcd & 212.2 & $\mathrm{~d}$ & 269.9 & $\mathrm{e}$ \\
\hline $\mathrm{F}_{1} \mathrm{~S}_{1}$ & & 119 & abcd & 192.5 & $\mathrm{e}$ & 290 & $\mathrm{~d}$ \\
\hline $\mathrm{F}_{1} \mathrm{~S}_{2}$ & & 122.4 & $a b c$ & 258.6 & $\mathrm{~b}$ & 330.5 & c \\
\hline $\mathrm{F}_{1} \mathrm{~S}_{3}$ & & 128.9 & $a b$ & 202.1 & de & 418 & $\mathrm{a}$ \\
\hline $\mathrm{F}_{2} \mathrm{~S}_{1}$ & & 116.5 & abcd & 239.4 & $\mathrm{c}$ & 319.6 & c \\
\hline $\mathrm{F}_{2} \mathrm{~S}_{2}$ & & 117.5 & abcd & 255.1 & $\mathrm{~b}$ & 353 & $\mathrm{~b}$ \\
\hline $\mathrm{F}_{2} \mathrm{~S}_{3}$ & & 132.9 & $\mathrm{a}$ & 335.1 & $\mathrm{a}$ & 408.3 & $\mathrm{a}$ \\
\hline $\operatorname{LSD}_{(0.05)}$ & & 16.71 & & 14.43 & & 6.05 & \\
\hline $\mathrm{CV}(\%)$ & & 10.13 & & 8.23 & & 9.48 & \\
\hline
\end{tabular}

$\mathrm{F}_{0^{-}}$Control, $\mathrm{F}_{1}$-Cowdung, $\mathrm{F}_{2}$ - Vermicompost and $\mathrm{S}_{1^{-}} 60 \times 30 \mathrm{~cm}, \mathrm{~S}_{2^{-}} 60 \times 40 \mathrm{~cm}, \mathrm{~S} 3-60 \times 50 \mathrm{~cm}$, 

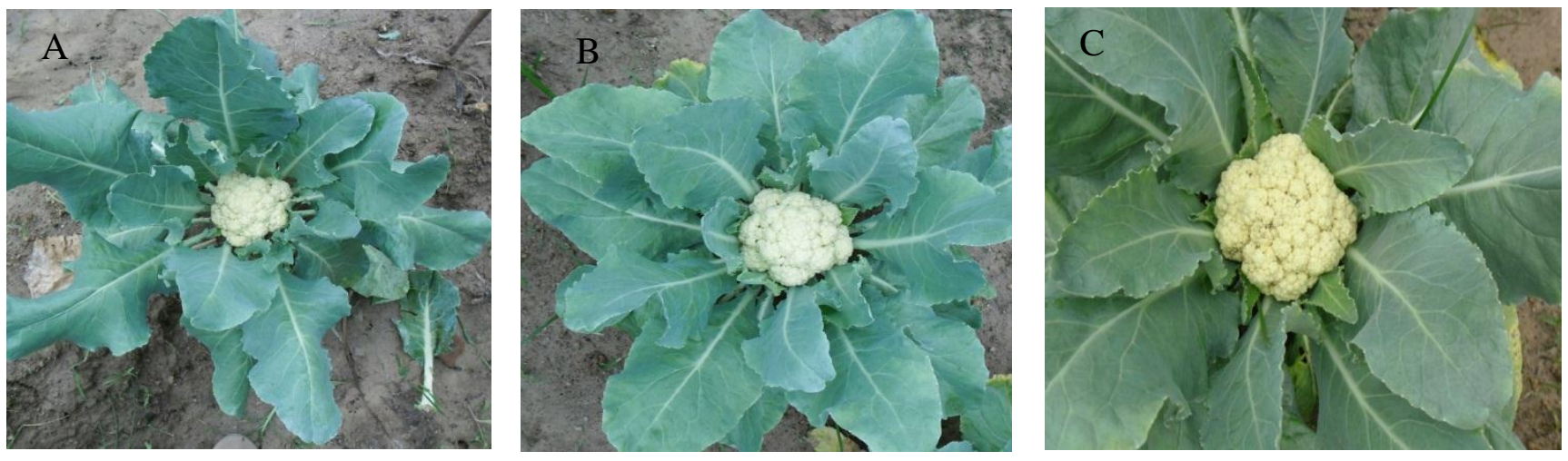

Plate 1. Picture showing curd of cauliflower with. A. Controlled Organic manure with $60 \mathrm{~cm} \times 30 \mathrm{~cm}$ Spacing which resulted small curd size; B. Cowdung with $60 \mathrm{~cm} \times 40 \mathrm{~cm}$ Spacing which resulted medium size curd; and $C$. Vermicompost with $60 \mathrm{~cm} \times 50 \mathrm{~cm}$ spacing which resulted bigger size curd.

\subsection{Dry weight of curd per plant (g)}

The maximum dry weight of curd $(62.3 \mathrm{~g})$ was observed in $\mathrm{F}_{2}$ and the minimum $(46.8 \mathrm{~g})$ was $\mathrm{F}_{0}$ at 70 DAT (Figure 9A). In addition, $S_{3}$ spacing produced maximum dry weight $(66.93 \mathrm{~g})$ and the minimum $(47.00 \mathrm{~g})$ was in $\mathrm{S}_{1}$ at same DAT (Figure 9B). In combined effect, the highest $(73.41 \mathrm{~g})$ and lowest $(37.83 \mathrm{~g})$ dry weight was observed in $\mathrm{F}_{2} \mathrm{~S}_{3}$ and $\mathrm{F}_{0} \mathrm{~S}_{1}$, respectively at 70 DAT (Figure 10).

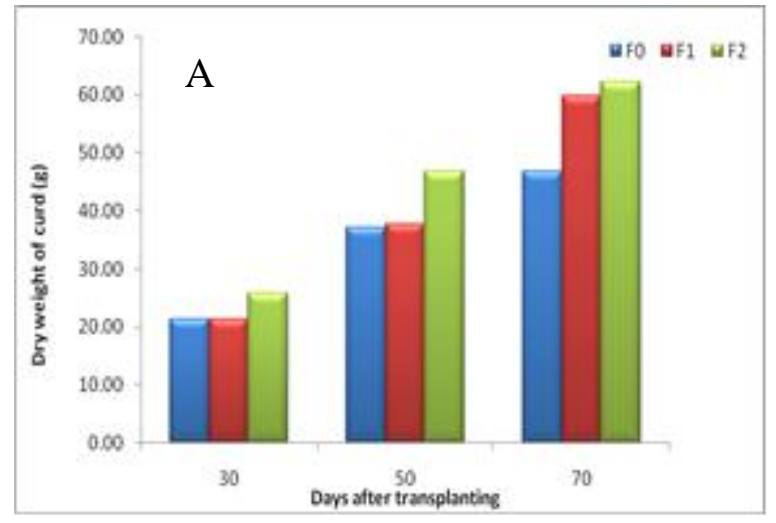

$\mathrm{F}_{0^{-}}$Control, $\mathrm{F}_{1}$ - Cowdung, $\mathrm{F}_{2}-$ Vermicompost and

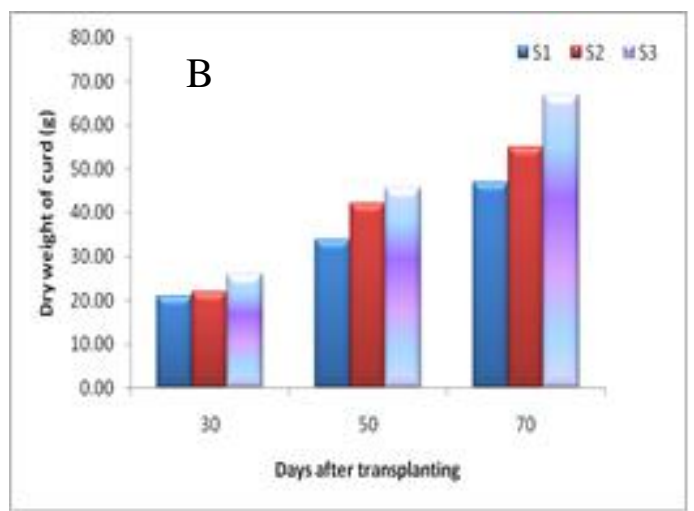

$\mathrm{S}_{1^{-}} 60 \times 30 \mathrm{~cm}, \mathrm{~S}_{2^{-}} 60 \times 40 \mathrm{~cm}, \mathrm{~S}_{3^{-}} 60 \times 50 \mathrm{~cm}$,

Figure 9. Effect of organic manure and spacing on dry weight of curd of cauliflower.

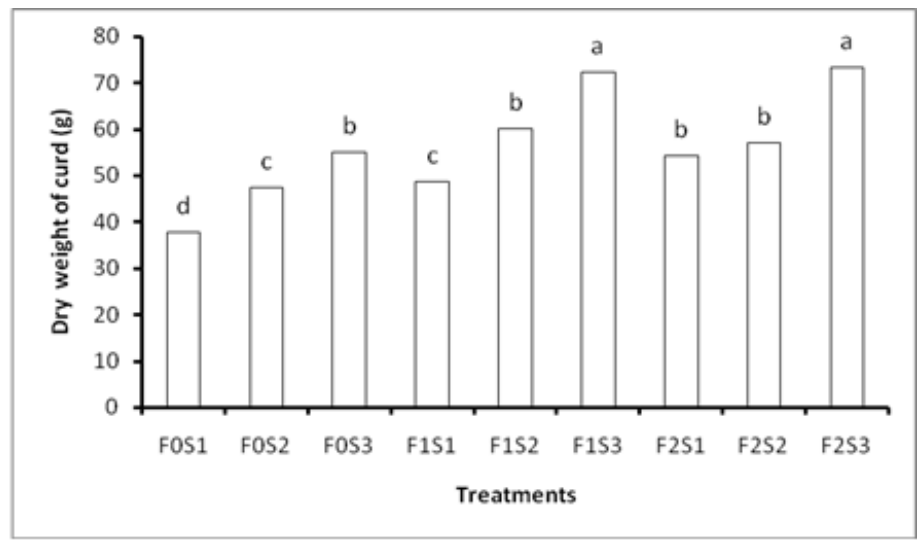

$\mathrm{F}_{0^{-}}$Control, $\mathrm{F}_{1}$-Cowdung, $\mathrm{F}_{2}-$ Vermicompost and $\mathrm{S} 1-60 \times 30 \mathrm{~cm}, \mathrm{~S}_{2^{-}} 60 \times 40 \mathrm{~cm}, \mathrm{~S} 3-60 \times 50 \mathrm{~cm}$,

Figure 10. Combined effect of organic manure and spacing on dry weight of curd of cauliflower at 70 DAT. 


\subsection{Yield (t ha $\left.{ }^{-1}\right)$}

Yields of cauliflower varied significantly due to different organic manure. The maximum yield $\left(13.0 \mathrm{tha}^{-1}\right)$ was found from $\mathrm{F}_{2}$. The minimum $\left(8.2 \mathrm{t} \mathrm{ha}^{-1}\right)$ in this respect was found from control (Figure 11A). The highest yield $\left(11.3 \mathrm{t} \mathrm{ha}^{-1}\right)$ was obtained from $S_{1}$ and the lowest $\left(10.6 \mathrm{t} \mathrm{ha}^{-1}\right.$ ) was from $S_{3}$ (Figure 11B). It was revealed that with the increases of spacing individual weight per plant increased. So, in spite of less population, total yield per plot may higher due to higher individual plant weight and optimum spacing ensured the highest yield with maximum vegetative growth. A significant combined effect of organic manure and spacing was also observed on yield of cauliflower per hectare. Though there is almost similar results are found from the treatment of controlled manure and cowdung manure because nitrogenous fertilizer was given repeatedly in field where cauliflower has been grown. The highest yield of cauliflower $\left(13.3 \mathrm{t} \mathrm{ha}^{-1}\right)$ was obtained from $\mathrm{F}_{2} \mathrm{~S}_{1}$ which is statistically similar to $\mathrm{F}_{2} \mathrm{~S}_{2}$ and the lowest $\left(7 . \mathrm{t} \mathrm{ha}^{-1}\right.$ ) was $\mathrm{F}_{0} \mathrm{~S}_{3}$ (Figure 12).

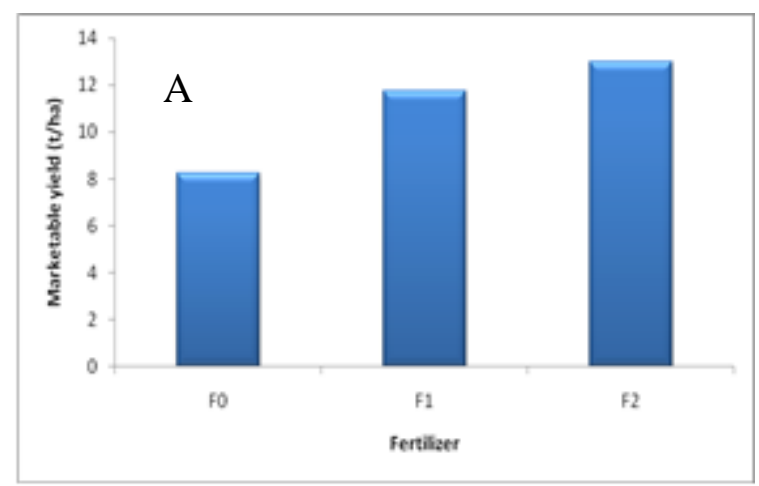

$\mathrm{F}_{0^{-}}$Control, $\mathrm{F}_{1^{-}}$Cowdung, $\mathrm{F}_{2}$ - Vermicompost and

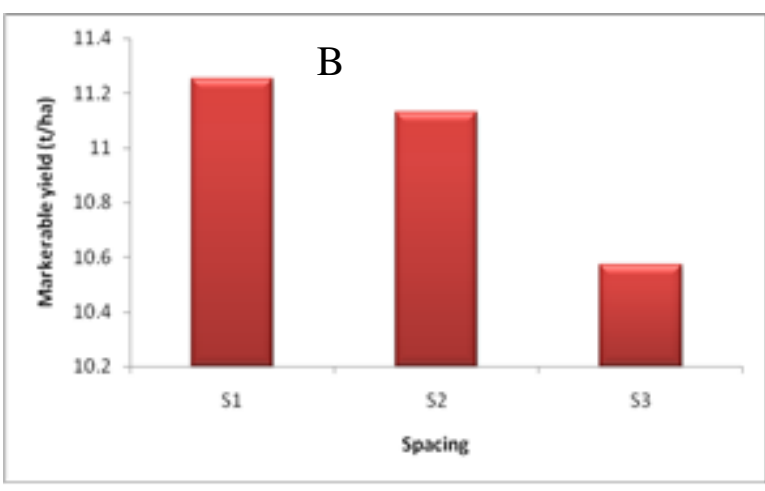

$\mathrm{S}_{1^{-}}-60 \times 30 \mathrm{~cm}, \mathrm{~S}_{2^{-}} 60 \times 40 \mathrm{~cm}, \mathrm{~S}_{3^{-}}-60 \times 50 \mathrm{~cm}$,

Figure 11. Effect of organic manure and spacing on yield of cauliflower.

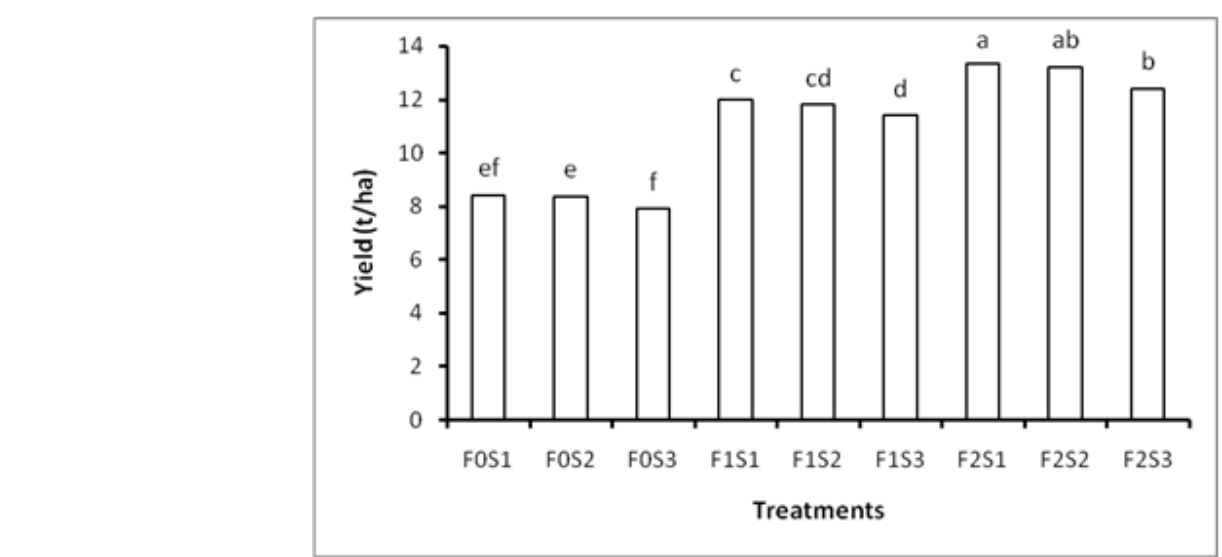

$\mathrm{F}_{0^{-}}$Control, $\mathrm{F}_{1^{-}}$Cowdung, $\mathrm{F}_{2}-$ Vermicompost and $\mathrm{S}_{1^{-}} 60 \times 30 \mathrm{~cm}, \mathrm{~S}_{2^{-}} 60 \times 40 \mathrm{~cm}, \mathrm{~S} 3-60 \times 50 \mathrm{~cm}$,

Figure 12. Combined effect of organic manure and spacing on yield of cauliflower.

\subsection{Cost and return analysis}

The total cost of production ranges between Tk. 88725 and 105600 per hectare among the different treatment combinations (Table 9). The variation was due to different cost of different types of manure. The highest cost of production Tk. 105600 per ha was involved in the treatment combination of vermicompost $\left(\mathrm{F}_{2} \mathrm{~S}_{1}\right)$, while the lowest cost of production Tk. 88725 per ha was involved in the combination of no fertilizer and manure $\left(\mathrm{F}_{0} \mathrm{~S}_{3}\right)$. Gross return of the different treatment combinations ranges between Tk 399900 and 237300 per ha. Among the different treatment combinations vermicompost with $60 \times 30 \mathrm{~cm}$ spacing $\left(\mathrm{F}_{2} \mathrm{~S}_{1}\right)$ gave the highest return Tk. 294300 per ha while the lowest net return Tk. 148575was obtained from the treatment combination of control with $60 \times 50 \mathrm{~cm}$ spacing $\left(\mathrm{F}_{0} \mathrm{~S}_{3}\right)$. The benefit cost ratio $(\mathrm{BCR})$ was found to be the highest (3.79) in the treatment combination of vermicompost with $60 \times 30 \mathrm{~cm}$ spacing $\left(\mathrm{F}_{2} \mathrm{~S}_{1}\right)$. Thus it was apparent that although vermicompost with $60 \times 30 \mathrm{~cm}$ spacing $\left(\mathrm{F}_{2} \mathrm{~S}_{1}\right)$ treatment gave the highest yield $\left(13.33 \mathrm{t} \mathrm{ha}^{-1}\right)$ and the highest gross return (Tk. 399900.00). 
Table 9. Cost and return of cauliflower due to fertilizer management and spacing treatments.

\begin{tabular}{|c|c|c|c|c|c|}
\hline $\begin{array}{l}\text { Treatment } \\
\text { combinations }\end{array}$ & $\begin{array}{l}\text { Marketable yield } \\
\left(\text { t. ha }^{-1}\right) 70 \text { DAT }\end{array}$ & $\begin{array}{l}\text { Gross return } \\
\left(\text { Tk. ha }{ }^{-1}\right)\end{array}$ & $\begin{array}{l}\text { Total cost of } \\
\text { production }\left(\mathrm{Tk} \mathrm{ha}^{-1}\right)\end{array}$ & $\begin{array}{l}\text { Net return } \\
\left(\text { Tk.ha }^{-1}\right)\end{array}$ & $\begin{array}{l}\text { Benefit cost } \\
\text { ratio (BCR) }\end{array}$ \\
\hline $\mathrm{F}_{0} \mathrm{~S}_{1}$ & 8.42 & 252600 & 88725 & 163875 & 2.85 \\
\hline $\mathrm{F}_{0} \mathrm{~S}_{2}$ & 8.38 & 251400 & 88725 & 162675 & 2.83 \\
\hline $\mathrm{F}_{0} \mathrm{~S}_{3}$ & 7.91 & 237300 & 88725 & 148575 & 2.67 \\
\hline $\mathrm{F}_{1} \mathrm{~S}_{1}$ & 11.99 & 359700 & 111225 & 248475 & 3.23 \\
\hline $\mathrm{F}_{1} \mathrm{~S}_{2}$ & 11.79 & 353700 & 111225 & 242475 & 3.18 \\
\hline $\mathrm{F}_{1} \mathrm{~S}_{3}$ & 11.4 & 342000 & 111225 & 230775 & 3.07 \\
\hline $\mathrm{F}_{2} \mathrm{~S}_{1}$ & 13.33 & 399900 & 105600 & 294300 & 3.79 \\
\hline $\mathrm{F}_{2} \mathrm{~S}_{2}$ & 13.21 & 396300 & 105600 & 290700 & 3.75 \\
\hline $\mathrm{F}_{2} \mathrm{~S}_{3}$ & 12.4 & 372000 & 105600 & 266400 & 3.52 \\
\hline
\end{tabular}

Here, Cauliflower seed @ Tk.8000 kg kn $^{-1}$ Cowdung @ Tk.600 t ${ }^{-1}$, Vermicompost @ Tk.750 t ${ }^{-1}$, Labour cost @ Tk. 250 day $^{-1}$, Price of cauliflower $30000 \mathrm{tk} \mathrm{ha}^{-1}$; Interest on running capital for 6 months (15\% of the total input cost); Miscellaneous cost (5\% of input cost). Here, $\mathrm{F}_{0}$-control, $\mathrm{F}_{1}-$ Cowdung, $\mathrm{F}_{2}-$ Vermicompost and $\mathrm{S}_{1}-60 \times 30 \mathrm{~cm}, \mathrm{~S}_{2}-60 \times 40 \mathrm{~cm}$, $\mathrm{S} 3-60 \times 50 \mathrm{~cm}$,

\section{Conclusions}

The highest (75.60, 350.5 and $487.6 \mathrm{~g}$ at 50, 60 and 70 DAT, respectively) curd weight with leaves was observed in the treatment combination $\mathrm{F}_{2} \mathrm{~S}_{3}$. The interaction effects of organic manure and plant spacing were significant in respect of pure curd weight per plant. The highest pure curd weight $(132.9,335.1$ and $408.3 \mathrm{~g}$ at 50,60 and 70 DAT, respectively) was observed in the treatment combination $\mathrm{F}_{2} \mathrm{~S}_{3}$ (Vermicompost with $60 \times 50$ $\mathrm{cm})$. The highest yield of cauliflower $\left(13.33 \mathrm{t} \mathrm{ha}^{-1}\right)$ was obtained from vermicompost with $60 \times 30 \mathrm{~cm}$ spacing $\left(\mathrm{F}_{2} \mathrm{~S}_{1}\right)$ treatment. The benefit cost ratio (BCR) was found to be the highest (3.79) in the treatment combination of vermicompost with $60 \times 30 \mathrm{~cm}$ spacing $\left(\mathrm{F}_{2} \mathrm{~S}_{1}\right)$. Considering the stated findings, it may be concluded that yield and yield contributing parameters are positively correlated with organic manure and spacing. However, white beauty planted and use of vermicompost with $60 \times 50 \mathrm{~cm}$ spacing would be beneficial for the farmers. Considering the situation of the present study, further studies in the following areas may be suggested-

a) Other combination of spacing may also use to optimize spacing for higher yield of cauliflower in summer season.

b) Available other organic manure with different amounts and their combination may be used for further study especially in summer season.

c) Doses of organic fertilizer may be rearranged for specification.

d) Further investigation may carry out in different agro ecological zones of Bangladesh before giving final recommendation.

\section{Conflict of interest}

None to declare.

\section{References}

Altieri M and FN Nicholls, 2003. Tolerance and effect of leaf fertilization treatments on vegetables. Gartebauwissenscharft, 51: 58-62.

BBS (Bangladesh Bureau of Statistics). 2011. Statistical Year Book of Bangladesh Bureau of Statistics. Available at the following web site: http://www.knowledgebank-brri.org.

Cook BD, TR Halbach, CJ Rosen, and JR Monerief, 1994. Effects of stream component on the agronomic properties of municipal solid waste compost. Sei. Util., 2: $75-87$.

FAO, 1986. Production year book. Food and Agricultural organization of the United Nations, Rome, Italy. P.141.

Fujime Y, 1983. Studies on thermal conditions of curd formation and development in cauliflower and broccoli, with special reference to abnormal curd development. Memoirs of Faculty of Agric. Kagawa Univesity, NO. 40.P.123.

Fujiwara T, H Yoshioka and F Sato, 2000. Effects of plant spacing and initial growth of seedlings after transplanting on the uniformity of cabbage heads at harvest. J. Japan. Soc. Hort. Sci., 69:315-222.

Ghanti, P, G Sounda, PK Jana and MG Som, 1982. Effect of levels of nitrogen, phosphorus and spacing on yield characters of cabbage. Veg. Sci., 9: 1-4. 
Gomez KA, and AA Gomez, 1984. Statistical Procedures for Agricultural Research (Second Edn.). John Wiley and Sons, New York. pp. 139-240.

Letourneau AF, 1996. The characteristics of mineral nutrition and yield formation in cabbage cultivar in relation to fertilizers and mineral uptake by cabbage plants. Agrokhimiya, 9: 61-67

Moniruzzaman M, 2011. Effect of plant spacings on the performance of hybrid cabbage (B. oleraceae var. capitata) varieties. Bangladesh J. Agril. Res., 36: 495-506

Rashid MM, 1999. Sabji Bigan.Text Book Division, Bangla Academy, Dhaka, Bangladesh.217.

Swarup V and SS Chatterjee, 1972. Cauliflower production. Econ. Bot., 26: 81-93.

Tejada M and JL Gonzalez, 2003. Effects of the application of a compost originating from crushed cotton gin residues on wheat yield under dry land conditions. Eur. J. Agron., 19: 357 - 368.

Sodkowski P, E Rekowska, 2003. The effect of covering and cultivation methods on crisp lettuce yields. Folia Hort., 15: 19-23

Steingrobe T and D Schenk, 1994. Effect of date of transplanting and plant spacing on seed yield and yield characters in lettuce (Lactuca sativa cv. Great lakes). Kamataka J. Agril. Sci., 5: 357-361.

Whalen JK, C Chang, GW Clayton and JP Carefoot, 2000. Cattle manure amendments can increase the pH of acid soils. Soil Sci. Soc. Am. J., 64: 962 - 966.

Widders IE and H Price, C.1989. Effects of plant density on growth and biomass partitioning in pickling cucumbers. J. Amer. Soc. Hort. Sci., 114: 751-755.

Wiebe HJ, 1972. Effect of temperature and light on growth and development of cauliflower. The optimal vernalization temperature and exposure time. Garten bouwissens chaft, 37: 393-303. 